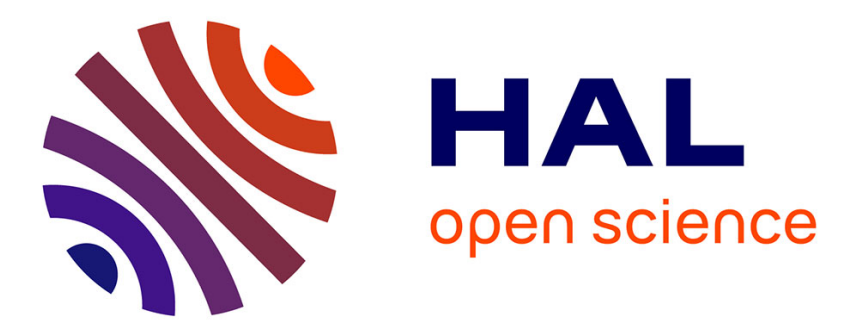

\title{
Genetic polymorphism and its potential relation to environmental stress in five populations of the European flounder Platichthys flesus, along the French Atlantic Coast
}

\author{
J. Marchand, E. Evrard, B. Guinand, J. Cachot, L. Quiniou, Jean Laroche
}

\section{To cite this version:}

J. Marchand, E. Evrard, B. Guinand, J. Cachot, L. Quiniou, et al.. Genetic polymorphism and its potential relation to environmental stress in five populations of the European flounder Platichthys flesus, along the French Atlantic Coast. Marine Environmental Research, 2010, 70 (2), pp.201. 10.1016/j.marenvres.2010.05.002 . hal-00602600

\section{HAL Id: hal-00602600 https://hal.science/hal-00602600}

Submitted on 23 Jun 2011

HAL is a multi-disciplinary open access archive for the deposit and dissemination of scientific research documents, whether they are published or not. The documents may come from teaching and research institutions in France or abroad, or from public or private research centers.
L'archive ouverte pluridisciplinaire HAL, est destinée au dépôt et à la diffusion de documents scientifiques de niveau recherche, publiés ou non, émanant des établissements d'enseignement et de recherche français ou étrangers, des laboratoires publics ou privés. 


\section{Accepted Manuscript}

Title: Genetic polymorphism and its potential relation to environmental stress in five populations of the European flounder Platichthys flesus, along the French Atlantic Coast

Authors: J. Marchand, E. Evrard, B. Guinand, J. Cachot, L. Quiniou, J. Laroche

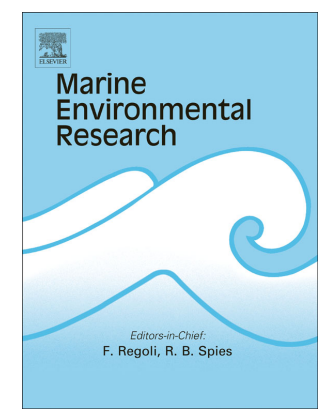

PII: S0141-1136(10)00069-3

DOI: 10.1016/j.marenvres.2010.05.002

Reference: MERE 3449

To appear in: Marine Environmental Research

Received Date: 15 February 2010

Revised Date: 5 May 2010

Accepted Date: 7 May 2010

Please cite this article as: Marchand, J., Evrard, E., Guinand, B., Cachot, J., Quiniou, L., Laroche, J. Genetic polymorphism and its potential relation to environmental stress in five populations of the European flounder Platichthys flesus, along the French Atlantic Coast, Marine Environmental Research (2010), doi: 10.1016/j.marenvres.2010.05.002

This is a PDF file of an unedited manuscript that has been accepted for publication. As a service to our customers we are providing this early version of the manuscript. The manuscript will undergo copyediting, typesetting, and review of the resulting proof before it is published in its final form. Please note that during the production process errors may be discovered which could affect the content, and all legal disclaimers that apply to the journal pertain. 


\title{
Genetic polymorphism and its potential relation to environmental stress in five populations of the European flounder Platichthys flesus, along the French Atlantic Coast
}

\author{
Marchand J. ${ }^{*}$, Evrard E. ${ }^{2}$, Guinand B. ${ }^{3}$, Cachot J. ${ }^{4}$, Quiniou L. ${ }^{2}$, Laroche J. ${ }^{2}$ \\ ${ }^{1}$ Université du Maine, EA 2160 Mer, Molécule, Santé, Le Mans F-72085, France \\ ${ }^{2}$ Université Européenne de Bretagne, UMR-CNRS-IRD 6539, Institut Universitaire Européen \\ de la Mer, Place Nicolas Copernic, Technopôle Brest-Iroise, F-29280 Plouzané, France \\ ${ }^{3}$ Université Montpellier 2, UMR CNRS 5554, Equipe Biologie Intégrative, place Eugène \\ Bataillon, cc63 - Bât $241^{\text {er }}$ étage, 34095 Montpellier Cedex 5, France \\ ${ }^{4}$ Institut des Sciences Moléculaires (ISM), UMR CNRS 5255, Groupe LPTC, Université \\ Bordeaux 1, 33405 Talence, France.
}

*Corresponding author:

Justine Marchand

EA 2160 Mer, Molécule, Santé

Université du Maine, UFR Sciences et Techniques

Avenue Olivier Messiaen

72085 Le Mans Cedex 9

FRANCE

Tel: +33.2 .43 .83 .32 .50$

Fax: +33.2.43.83.39.17

E-mail: justine.marchand@univ-lemans.fr 


\section{Abstract}

In this study, new DNA markers were explored for the flounder Platichthys flesus. cDNA and genomic sequences of the genes encoding the glyceraldehyde-3-phosphatedeshydrogenase (GAPDH), the cytosolic creatine kinase (CK), the prostaglandin D synthase (PGDS) and the betain homocystein methyltransferase (BHMT) were characterized. The tumour suppressor p53 gene structure was already described. A PCR-SSCP (Single Strand Conformation Polymorphism) analysis was finally conducted to study the genetic polymorphism of different populations of flounders collected along the French Atlantic coast. Four highly contaminated French estuaries (Seine, Vilaine, Loire and Gironde) were sampled and compared to a reference estuary (Ster) to explore possible selective effect of the environment on specific allelic frequencies. Our results showed that two loci p53and PGDS, could be potential markers of chemical stress: p53A allele frequency increased in contaminated systems compared to the reference system. In the Vilaine estuary, PGDS polymorphism could be related to pesticide stress.

Keywords: flounder; contamination; gene; polymorphism; PCR-SSCP; selection 


\section{Introduction}

Coastal ecosystems have been subjected for several decades to increased anthropogenic pollution (hydrocarbons, pesticides...) and to other environmental stressors (hypoxia, temperature increase, eutrophication ...). Some of these stressors are known to induce modifications of the genetic structure of populations living in these environments (Gillespie and Guttman, 1993; Moraga et al., 2002; Tanguy et al., 2002), retaining the fittest genotypes in the perturbated systems and thus conducting to changes in allelic frequencies (Ma et al., 2000; Bickham et al., 2000). Moreover, modifications of the genetic variability within and between populations may reduce their adaptability to new environments. Allelic variation at any loci that contribute to a modification of the phenotype could be acted upon by selection (Carvalho, 1993). Therefore, specific genotypes may be selected in natural populations because they contribute to the resistance to the toxic effects of pollutants; the relative proportion of these "resistant" genotypes may increase in chronically contaminated populations (Heithaus and Laushman, 1997; Larno et al., 2001).

Allozyme markers have been extensively studied on aquatic organisms, particularly to evaluate the impact of chemical stress on the genetic structure of fish populations living in heavily contaminated rivers (Gillespie and Guttman, 1993, 1999; Benton et al., 1994; Foré et al., 1995; Heithaus and Laushman, 1997). But few studies focused directly on the genetic polymorphism of specific candidate genes, at the DNA level. Thus, the aim of this study was to characterize new nuclear genetic markers in the European flounder Platichthys flesus. We analyzed the variability of five genes: the glyceraldehyde-3-phosphate deshydrogenase (GAPDH), the cytosolic creatine kinase (CK), the prostaglandin D synthase (PGDS), the betain homocystein methyltransferase (BHMT) and the p53 genes. Four of them (GAPDH, CK, PGDS and BHMT) were partially isolated in a previous work performed on flounders exposed to different pesticides, and differentially regulated during the exposition (Marchand et al., 2006). The tumour suppressor gene p53 was characterized previously (Cachot et al., 1998, 2000)

The glyceraldehyde-3-phosphate dehydrogenase (GAPDH) enzyme is a classical glycolytic protein playing an essential role in the carbohydrate metabolism. Firstly, the GAPDH mRNA level has been commonly used as an invariant internal standard for various gene expression assays, considering that this gene would be constitutively expressed. However from the last decade, it was demonstrated that GAPDH could be a multifunctional 
modulator implicated in diverse cellular pathways, especially those involved in induced apoptosis and neurodegenerative disorders (Chuang et al., 2005; Sirover, 2005).

Creatine kinase (CK) enzymes, specifically located in sites of energy demand or production, are linked to a phosphocreatine/creatine circuit found in particular cells. Two CK isoforms may be found in vertebrate skeletal muscle: a cytosolic isoform (designated MMCK) and a mitochondrial isoform (designated Mt-CK) (Wallimann et al., 1992). Phosphocreatine production, catalyzed by Mt-CK, is favoured at the mitochondrial membrane level. The reverse reaction is favoured at sites of ATP utilization and is catalyzed by MM-CK (Hochachka et al., 1983; Wallimann et al., 1992). Transgenic mice whose skeletal muscles are deficient in MM-CK are incapable of burst activity (van Deursen et al., 1993).

The betaine homocysteine methyltransferase (BHMT) enzyme catalyzes a key reaction at the convergence of the folate and the methionine cycles. This enzyme plays an important functional role in homocysteine remethylation ( $\mathrm{Li}$ et al., 2008). Homocysteine is a highly reactive compound; highest concentrations inducing oxidative damage (Refsum et al., 1998). As many different methyltransferases (Hodgson and Levi, 1992), BHMT may possibly act as a phase II metabolizing enzyme. Despite intense interest in elevated circulating homocysteine levels as a possible risk factor for human cardiovascular disease, osteoporosis, dementia, and complications of pregnancy (Hermann, 2006), surprisingly little is known with regard to common genetic variation, even in humans.

The lipocalin-type prostaglandin D synthase (L-PGDS) is a bifunctional protein possessing both the ability to synthesize prostaglandins and to serve as a carrier protein for lipophilic molecules (Fujimori et al., 2006). L-PGDS has been extensively studied in mammalian species, whereas little is known about non-mammalian forms. L-PGDS concentrations are useful for the diagnosis of several profound disorders (neurological, cardiovascular, and renal) and multiple sclerosis and cancers in humans (Su et al., 2001; Hirai et al., 2001; Chen et al., 2004). Moreover, Vogel (2000) showed that not only endogenous stimuli but also drugs and environmental chemicals can activate prostaglandin D synthase expression, especially in certain target tissues that possess low CYP monooxygenase activity. In particular, Hodgson and Levi $(1991,1992)$ showed that pesticides may be metabolized by prostaglandin synthetase.

To our knowledge very few studies have been published on the DNA polymorphism of the four previous genes and most concerned humans (Tso et al., 1985; Greenblatt et al., 1994; Li et al., 2008). 
The last studied gene is the tumour suppressor p53 gene. The human homologue encodes a $53 \mathrm{kDa}$ transcription factor which regulates cell cycle, apoptosis and DNA integrity in response to stress factors such as DNA damage, oncogene activation or hypoxia (see Pluquet and Hainaut, 2001). To date, this gene has been partially or completely sequenced in about eighteen fish species including the European flounder (Cachot et al., 1998). Although the p53 gene sequence has diverged in the course of vertebrate evolution (Cachot et al., 2000), some of the critical functions are conserved. Indeed, fish p53 acts as a transcription factor which inhibits cell growth (Langheinrich et al., 2002; Cachot et al., 2004) and promotes apoptosis in response to DNA-damage induction (Langheinrich et al., 2002; Berghmans et al., 2005). In contrast to human, fish p53 gene is infrequently mutated in sporadic and chemically-induced tumours (Cachot et al., 2000; Franklin et al., 2000; Sueiro et al., 2000).

In this study, the isolation and characterization of the full-length cDNA and genomic sequence that encodes $P$. flesus GAPDH, CK, BHMT and PGDS are described, the p53 gene sequence being already described by Cachot et al. (2000). A PCR-SSCP (Single Strand Conformation Polymorphism) study was finally conducted to study the genetic polymorphism of different populations of flounders collected along the French Atlantic coast and to explore possible selective effects of the environment on specific allelic frequencies.

\section{Materials and methods}

\section{Biological model}

The European flounder Platichthys flesus (L.) is a benthic flatfish commonly distributed in the East Atlantic Ocean. During its juvenile period, it lives in estuaries and brackish waters. This species has been used for several decades as a sentinel species for pollution monitoring in the North-East Atlantic (Vethaak et al., 2009).

\section{DNA markers}

\section{cDNA characterization}

The characterization of four $P$. flesus cDNA sequences was performed: the glyceraldehyde-3-phosphate deshydrogenase (GAPDH), the creatine kinase (CK), the prostaglandin D synthase (PGDS) and the betain homocystein methyltransferase (BHMT). The procedures for the generation of cDNA of the 5' and 3' untranslated regions (UTRs) for 
these four sequences were carried out according to the commercial protocol for the rapid amplification of 3'/5' cDNA ends (5'/3' RACE Kit, Roche, Mannheim, Germany), using specific primers. Primers were designed based on the partial cDNA sequences of $P$. flesus GAPDH, CK, PGDS and BHMT previously identified (Marchand et al., 2006): Table 1. Total RNA was extracted from the hepatopancreas and the muscle of $P$. flesus according to the method based on extraction in guanidium isothiocyanate (Strohman et al., 1977). cDNA was synthesized from $20 \mu \mathrm{g}$ of RNA using the oligo dT race primer (Table 1), $2 \mathrm{mM}$ dNTPs, and M-MLV reverse transcriptase (Promega, Madison, WI, USA), and was then purified using the Wizard ${ }^{\circledR}$ DNA Clean-Up System (Promega).

$200 \mathrm{ng}$ of reverse-transcribed products were used for the PCR amplification of the 3'UTRs in a final volume of $25 \mu \mathrm{l}$ with $1 \mathrm{x}$ reaction buffer (Interchim), $1.5 \mathrm{mM} \mathrm{MgCl}_{2}$, $0.04 \mathrm{mM}$ dNTPs mixture, $1 \mu \mathrm{M}$ of the race primer and the specific reverse primer $\mathrm{R}_{1}$ (Table 1 ), $0.25 \mathrm{U}$ of Taq Uptitherm DNA polymerase (Interchim) and submitted to the following program in a thermocycler (Applied Biosystems): $94^{\circ} \mathrm{C}$ for $2 \mathrm{~min}$, followed by 35 cycles at $94^{\circ} \mathrm{C}$ for $30 \mathrm{~s}, \mathrm{Ta}^{\circ} \mathrm{C}$ for $30 \mathrm{~s}$ and $72^{\circ} \mathrm{C}$ for $1 \mathrm{~min}$ and an additional step at $72^{\circ} \mathrm{C}$ for $10 \mathrm{~min}$.

Amplification of the 5' UTRs were carried out according to the following procedure: $200 \mathrm{ng}$ of reverse transcription product was treated with terminal deoxynucleotidyl transferase (Promega, Madison, WI, USA) and dATP to generate a polyA tail at the 5' end. A first PCR amplification was performed on this product with $1 \mu \mathrm{M}$ of the oligo dT race primer and the specific forward primer $F_{1}$ (Table 1) and submitted to the following program: $94^{\circ} \mathrm{C}$ for $2 \mathrm{~min}$, followed by 15 cycles at $94^{\circ} \mathrm{C}$ for $15 \mathrm{~s}, \mathrm{Ta}^{\circ} \mathrm{C}$ for $30 \mathrm{~s}$ with an increase of $0.2^{\circ} \mathrm{C}$ per cycle, $72^{\circ} \mathrm{C}$ for $2 \mathrm{~min}$, then 25 cycles at $94^{\circ} \mathrm{C}$ for $15 \mathrm{~s}, \mathrm{Ta}+3^{\circ} \mathrm{C}$ for $30 \mathrm{~s}, 72^{\circ} \mathrm{C}$ for $2 \mathrm{~min}$, and a final step at $72^{\circ} \mathrm{C}$ for $10 \mathrm{~min}$. A second PCR amplification was performed using $1 \mu 1$ of the amplification products, $1 \mu \mathrm{M}$ of the race primer and the specific forward primer 2 (Table 1), and submitted to the program cited above.

PCR products were analyzed on a $1 \mathrm{X}$ TAE (Tris-Acetate-EDTA)/1\% agarose gel (130 Volts for 1 hour), visualized with UV light after staining with ethidium bromide, excised from agarose and purified using the QIAEX II Gel Extraction Kit (Qiagen) following the manufacturer's instructions. Purified PCR products were then ligated to the pGEM-T easy plasmid vector (Promega) and transfected into Escherichia coli DH5a strain. Recombinant bacteria were identified by blue/white screening and white colonies were grown in LuriaBertani medium (with $100 \mathrm{mg} . \mathrm{L}^{-1}$ ampicillin) from which the vector was extracted using an alkaline lysis plasmid preparation. Size screening was performed by PCR amplification using T7 and SP6 universal primers and selected clones were sequenced using a LiCOR IR ${ }^{2}$ 
(Sciencetech, Lincoln, NE, USA) and the Thermo Sequenase Primer Cycle Sequencing Kit (GE Healthcare Europe, Freiburg, Germany). Sequences obtained were then subjected to a homology search through the BLASTX program available at the NCBI Genbank biocomputing site (http://www.ncbi.nlm.nih.gov/BLAST/) (Altschul et al., 1990). The deduced amino acid sequences were obtained using the translate software available at the ExPASy (Expert Protein Analysis System) server of the Swiss Institute of Bioinformatics (http://www.expasy.org/tools/). Their molecular weight and isoelectric point were calculated using the MWCALC software (Infobiogen, France). Entire cDNA sequences obtained were deposited in the NCBI Genbank biocomputing site.

\section{Gene characterization}

Genomic DNA was extracted from fin tissue. About $100 \mathrm{mg}$ of fin were placed in extraction buffer (0.3 M Tris, $\mathrm{pH}$ 8, $0.02 \mathrm{M}$ ethylene diamine tetra-acetic acid [EDTA], 0.1M $\mathrm{NaCl}$ ) together with sodium dodecyl sulphate (SDS) and proteinase $\mathrm{K}$ at a final concentration of $0.6 \%$ and $0.1 \mathrm{mg} \cdot \mathrm{ml}^{-1}$, respectively. The mixture was then incubated at $55^{\circ} \mathrm{C}$ until complete dissolution of tissue. $\mathrm{NaCl}$ was then added to a final concentration of $1.3 \mathrm{M}$. After homogeneisation, samples were centrifuged at $3000 \mathrm{~g}$ at $20^{\circ} \mathrm{C}$ for $10 \mathrm{~min}$. The supernatant was taken and two phenol/chloroform/isoamyl alcohol (25:24:1) extractions performed. DNA was precipitated with absolute ethanol, recovered by centrifugation $30 \mathrm{~min}$ at $12000 \mathrm{~g}$ at $4^{\circ} \mathrm{C}$, rinsed with $70^{\circ}$ ethanol, dried and dissolved in $1 \mathrm{~mL}$ of TE buffer $(10 \mathrm{mM}$ Tris, $\mathrm{pH} 8,1 \mathrm{mM}$ EDTA).

The different gene sequences were amplified using primers combinations based on the cDNA sequences identified previously (Table 2). Two hundred nanograms of genomic DNA, $1.5 \mathrm{mM} \mathrm{MgCl}_{2}, 0.04 \mathrm{mM}$ dNTPs mixture, $1 \mu \mathrm{M}$ of each primer and $0.25 \mathrm{U}$ of Taq Uptitherm DNA polymerase were submitted to the following amplification: $94^{\circ} \mathrm{C}$ for $5 \mathrm{~min}$, followed by 40 cycles at $94^{\circ} \mathrm{C}$ for $30 \mathrm{~s}, \mathrm{Ta}^{\circ} \mathrm{C}$ for $40 \mathrm{~s}, 72^{\circ} \mathrm{C}$ for $1 \mathrm{~min} 30 \mathrm{~s}$, and a final step at $72^{\circ} \mathrm{C}$ for 10 min. Cloning and sequencing were performed according to the procedures described previously and the gene sequences were deduced from the overlapping fragments sequenced and deposited in the NCBI Genbank biocomputing site.

\section{PCR-SSCP (Single Strand Conformation Polymorphism) analysis}

The SSCP analysis is one of the simplest, most reliable and most sensitive method for detection of mutations based on PCR (Sheffield et al., 1993) and this technique allows the detection of $99 \%$ of the mutations from fragments of 200 to 300 bp length (Orita et al., 1989). 
For each gene, primers were designed to amplify each exon (except the too short exons) or two adjacent exons. We have optimized the technique to detect only single nucleotide polymorphisms (SNPs). Afterwards, a selection of SNPs was made, based on the polymorphism level and on the reproducibility of the band patterns. We have thus chosen: exon 3/4 for the GAPDH gene, exon 5/6 for the CK gene, exon 3 for the BHMT, exon 4/5 for the PGDS gene and exon 5 for the p53 gene (08919). Primers used for these amplifications are presented in Table 3. All PCR amplifications were performed in a volume of $25 \mu \mathrm{L}$ containing $1 \times$ Taq polymerase buffer, $2 \mathrm{mM} \mathrm{MgCl} 2,40 \mu \mathrm{M}$ deoxynucleotides (dNTPs), $1 \mu \mathrm{M}$ of each primer, 0.5 units of Taq Uptitherm DNA polymerase and about $100 \mathrm{ng}$ of total genomic DNA and submitted to the following program: $94^{\circ} \mathrm{C}$ for $5 \mathrm{~min}, 40$ cycles of $30 \mathrm{~s}$ at $94^{\circ} \mathrm{C}, 40 \mathrm{~s}$ at $\mathrm{Ta}^{\circ} \mathrm{C}$, and $1 \mathrm{~min} 30 \mathrm{~s}$ at $72^{\circ} \mathrm{C}$, with a final elongation of $10 \mathrm{~min}$ at $72^{\circ} \mathrm{C}$. The PCR products were then combined with $20 \mu$ l of loading buffer (bromophenol blue, xylem cyanol, saccharose), heated for $5 \mathrm{~min}$ at $95^{\circ} \mathrm{C}$, then rapidly chilled on ice to melt and retain single strand DNA. After loading on a neutral 8\% polyacrylamide gel (37.5:1, acrylamide: bisacrylamide), the samples were electrophoresized at a constant voltage $(120 \mathrm{~V})$ in a $0.6 \times$ TBE buffer, for 16-20 h at either ambient temperature (PGDS and p53) or $4^{\circ} \mathrm{C}(\mathrm{GAPDH}, \mathrm{CK}$ and BHMT). After electrophoresis, the gels were stained with ethidium bromide and visualised under ultraviolet light. Single strand DNA bands from the PCR products visualized on the gel were gel-purified by diffusion into water by freezing at $-20{ }^{\circ} \mathrm{C}$ and thawing. Double-strand DNAs were obtained from these recovered DNAs by PCR amplification using the same primers as for SSCP. PCR products were then purified, cloned and sequenced as described above. The SWISS Model 3.5 software available via the ExPASy server (Schwede et al., 2003) was used to determine the secondary structure of the different variants when nonsynonymous changes occurred.

\section{Studied sites and sample processing}

Adult flounders were collected in four French polluted estuaries (Gironde, Loire, Seine and Vilaine) and one moderately contaminated estuary (Ster) considered as the 'reference site' (low domestic, agricultural and industrial effluents) (Marchand et al., 2003; Figure 1). The Gironde, Loire, Seine and Vilaine estuaries are subjected to strong anthropogenic influences and are chronically polluted by mixtures of chemicals. The Seine undergoes a diffuse contamination (complex mixture of organic chemicals) similar to the one reported in heavily polluted estuaries of North America (Munschy et al., 1997; Cachot et al., 2006). The chemical stress of the Loire estuary is rather similar but the level of organic 
pollutant concentrations is however three times lower than the level found in the Seine estuary (Marchand et al., 2003). The Gironde estuary is mainly characterized by high levels of heavy metals such as zinc, cadmium and copper (RNO, 2001; Marchand et al., 2003) and water analyses carried out in the Vilaine estuary, between 1996 and 1999, displayed particularly high levels of pesticides (especially atrazine, diuron and isoproturon) (Forget, 1998; SAGE Vilaine, 2000) as a result of intensive agriculture. The Vilaine estuary (and the Loire to a lesser extent) is also known to experience hypoxic events (Menesguen et al., 2001).

A recent study underlined that chemical concentrations detected in flounder tissues allowed to consider the Ster estuary as a reference site, displaying a low level of contaminants (PCBs, PAH metabolite, metals) compared to other estuaries (Evrard et al., 2010). Furthermore, several studies confirmed that the average flounder growth rate was consistently higher in the Ster estuary compared to the polluted systems: Seine, Vilaine, Loire, Gironde (Laroche et al., 2002; Marchand et al., 2003, 2004; Evrard et al., 2010). As no North-South increase of the growth rate was observed over the contaminated estuaries, we suggest that globally the thermal regimes of these systems are not significantly different.

Forty flounders from each estuary were caught in winter (January and February 2003) by gillnets (Ster) and trawling operations (Gironde, Loire, Seine and Vilaine). The average sex ratio (males/females) and age (otolith observation) were estimated for the Ster, the Gironde, the Loire, the Seine and the Vilaine respectively: 0.29 and $2.7 \pm 0.3$ years; 0.48 and 2.6 \pm 0.2 years; 0.14 and $2.7 \pm 0.2$ years; 0.29 and $2.7 \pm 0.3$ years; 0.58 and $1.2 \pm 0.2$ years. Muscle and hepatopancreas were collected from each individual, flash-frozen in liquid nitrogen for RNA extraction (cDNA characterization), brought back to the laboratory and stored at $-80^{\circ} \mathrm{C}$ until use. Fragments of fin were also preserved in alcohol for DNA extraction.

\section{Genetic analysis}

\section{Statistical and population genetic analysis}

The population genetic parameters (allelic frequencies for each locus, observed heterozygosity (Ho), expected heterozygosity (He) based on Hardy-Weinberg equilibrium) were calculated per population with the GeneClass2 software (Piry et al., 2004). Allelic frequencies were analysed with $\chi^{2}$ conformity tests to detect potential heterogeneity between contaminated and uncontaminated populations. Differences in heterozygosity between the polluted and control sites were evaluated with a paired $t$-test using the locus as unit of replication (Leberg, 1992). Deviation from Hardy-Weinberg equilibrium was determined 
within each population for each locus by computing the inbreeding coefficient Fis with the GENETIX 4.05 software (Belkhir et al., 2004). The significance of Fis was tested with the GENEPOP 3.2 software (Raymond and Rousset, 1995) using the Markov chain method (10 000 dememorisation steps, 1000 batches, 3000 iterations) to obtain unbiased estimates of the exact p-value (Guo and Thompson, 1992).

The genetic differentiation was assessed using Wright's $\mathrm{F}_{\mathrm{ST}}$ (Wright, 1969) and exact tests of population differentiation (Raymond and Rousset, 1995). Single and multi-locus global $F_{\text {ST }}$ was estimated using Weir and Cockerham's $\theta$ (Weir and Cockerham, 1984) with the GENETIX 4.05 software (Belkhir et al., 2004) and tested by permutated data sets (5000). Single and multi-locus global exact test of population differentiation was calculated with the GENEPOP 3.2 software (Raymond and Rousset, 1995) using a Markov chain method (10 000 dememorisation steps, 1000 batches, 3000 iterations). Furthermore, Fst by locus was assessed for each pair of locations. Control of the false discovery rate (FDR test) was carried out in multiple testing (Benjamini and Yekutieli, 2001).

\section{Results}

\section{Molecular characterization}

The accession numbers for the different cDNA and DNA sequences are presented in Table 4 as well as the length of the coding region (and the corresponding amino acids, molecular weight and isoelectric point), the length of the 5' and 3' UTR sequences and the size of the corresponding gene. The exon/intron structure for each gene is presented in Figure 2. All the introns of the different genes start and end with the consensus GT and AG splicing signals.

For the GAPDH cDNA, the typical eukaryotic GAPDH signature ASCTTNCL related to the substrate binding was found from the amino acid positions 148 to 155 (Sirover, 1999). Amino acids putatively related to the $\mathrm{NAD}^{+}$binding ( $\mathrm{D}$ and $\mathrm{E}$ in amino acid positions 37 and $315)$ and the sites putatively related to the inorganic phosphate binding were also found ( $\mathrm{S}, \mathrm{T}$, $\mathrm{D}$ and $\mathrm{T}$ in positions 149, 151, 196 and 209) in the GAPDH sequence of Platichthys flesus (Aoki et al., 2000; Liaud et al., 2000). For the cytosolic CK cDNA, lysine (K) charge clamp residues (Hornemann et al., 2000) were found in the CK sequence of Platichthys flesus in amino acid positions 105 and 116. These residues have been implicated in binding of mammalian MM-CK to the sarcomere M-line (Hornemann et al., 2000), allowing MM-CK to 
be coupled directly to myosin ATPase activity (Wallimann and Eppenberger, 1985). The consensus sequence AATAAA was also present in the four sequences described in this study, respectively 20bp, 12bp, 16bp and $15 \mathrm{bp}$ upstream from the polyadenylation site for GAPDH, CK, BHMT and PGDS.

\section{Polymorphism analysis}

\section{Genetic variability within population}

PCR-SSCP analysis performed at 5 loci in 189 flounders from four different estuaries allowed us to characterize: 5 alleles for GAPDH and PGDS, 4 alleles for CK and 2 alleles for BHMT and p53. Allelic frequencies and multi-locus heterozygosities are presented in Table 5. For GAPDH locus, a decrease of A allele frequency and an increase of B allele frequency were observed in the Gironde population compared to the Ster population, this trend being however not significant $(\mathrm{p}>0.05)$. A moderate decrease in the CK A allele frequency was observed in the Gironde estuary with respect to the reference site (Ster). The p53 A allele frequency was globally higher $(\mathrm{p}>0.05)$ in contaminated populations (Gironde, Loire, Seine and Vilaine) compared to the "reference" site (Ster); this increase ranging from $12.4 \%$ (Gironde and Loire) to $13.7 \%$ (Seine). In the Vilaine estuary, a mean increase of $10 \%$ in BHMT and PGDS A allele frequencies was observed compared to the Ster estuary whereas a $12.5 \%$ decrease in PGDS A allele frequency was observed for Seine compared to Ster. A 10\% decrease in PGDS B allele frequency was also observed in Vilaine and Gironde estuaries compared to the reference site (Ster).

Mean observed heterozygosities were globally higher in the Ster and Gironde populations ( $\mathrm{Ho}=0.36$ and 0.39 respectively) than in the Loire, Seine and Vilaine populations $(\mathrm{Ho}=0.32,0.34,0.29$ respectively), but not significantly different (all t-values $<1.48, \mathrm{p}>0.05$, with 4 df). A significant heterozygote deficit (Fis $>0, p<0.01$ ) was detected for GAPDH locus in all estuaries (Table 6). Globally, no significant departure from Hardy-Weinberg equilibrium was detected for the other loci. However a moderate heterozygote deficit for p53 locus was observed for the Seine and Loire populations ( $p>0.05)$, whereas a moderate heterozygote excess was observed in the Vilaine and Gironde populations ( $p>0.05$ ) (Table 6). Moreover, a marked but un-significant heterozygote deficit was observed for the BHMT locus in the Loire estuary. No departure from Hardy-Weinberg equilibrium was observed for the PGDS locus (Table 6). 


\section{Genetic differentiation between populations}

On the whole data set (Table 7), multi-locus Fst estimation indicated a moderate level of genetic differentiation (Fst $=0.005, \mathrm{p}>0.05$ ) between populations, confirmed by a nonsignificant exact test of genic differentiation $(\mathrm{p}=0.07)$. Single locus Fst and exact tests suggested that particular loci (CK, p53 and principally PGDS) could explain a possible differentiation between populations (Table 7).

The estimation of Fst by locus and by pair of estuaries indicated that several pairs of populations displayed genetic differentiation (Table 8). For GAPDH, a genetic differentiation was observed between the Gironde and Loire populations as well as between the Gironde and Seine populations $(\mathrm{p}<0.05)$. For CK, a differentiation was detected between the Seine and Gironde populations $(\mathrm{p}<0.05)$. For $\mathrm{p} 53$, a general differentiation was found between the Ster (reference site) and the four contaminated populations (Table 8), but this trend was however not significant $(\mathrm{p}>0.05)$. For BHMT, the genetic differentiation was better marked between Ster and Vilaine populations, than between Gironde / Vilaine or Seine / Vilaine (Table 8). For PGDS locus, a significant differentiation was observed between Seine and Vilaine and between Seine and Gironde $(\mathrm{p}<0.05)$ (Table 8). However, after performing a FDR test on the levels of differentiation detected by locus and by pair of populations, the differentiations for the PGDS locus remained significant.

\section{Allele sequencing}

The sequences of the different alleles revealed both exonic and intronic polymorphism (Figure 3). Mutations detected for GAPDH, CK, BHMT and p53 were all identified as 1) synonymous (silent) mutations (no amino acid replacement) and/or 2) mutations in the noncoding regions (introns). On the contrary, 3 out of the 5 alleles detected in the PGDS locus (B, $\mathrm{C}$ and $\mathrm{E}$ alleles) displayed a fragment with a polymorphism resulting in a modification of the corresponding amino acid, the sequence of allele A being used as a reference: valine was changed by alanine for allele B, aspartic acid by glutamic acid for allele $\mathrm{C}$, and valine by isoleucine for allele E (Figure 3). The SWISS Model 3.5 was used to determine the secondary structure of the different PGDS variants but revealed no difference.

\section{Discussion}

\section{Molecular characterization}


The exon/intron structures obtained for the different genes in this study were compared to the very few known gene structures available in the databases (essentially mammal's sequences). Sequences of the creatine kinase gene (MM-CK gene) from Platichthys stellatus ( $\underline{\mathbf{G U 3 2 4 2 5 6}}$ ) and Homo sapiens $(\underline{\mathbf{N C} \mathbf{0 0 0 0 1 9}})$ show the same structure than the sequence identified for P. flesus, with 7 exons (same length) and 6 introns, the length of the introns being however slightly different for P. stellatus and largely different for $H$. sapiens compared to $P$. flesus sequence. Indeed, the DNA sequence length of $H$. sapiens reaches 16463 bp compared to $2369 \mathrm{bp}$ and $3091 \mathrm{bp}$ for respectively $P$. flesus and $P$. stellatus. The comparison of the GAPDH gene between P. flesus and H. sapiens ( $\underline{\text { NG_007073) }}$ shows the same structure with 11 short exons (however not of the same length). The coding sequence length differs between the two species (999 and 1226 bp respectively for $P$. flesus and $H$. sapiens) a well as the length of the gene (4086 and 11908 bp respectively). The BHMT and PGDS genes also show the same structure between P. flesus and H. sapiens $\underline{\text { NC } \mathbf{0 0 0 0 0 5}}$ and $\underline{\text { NC } 000009}$ for respectively BHMT and PGDS), the length of the genes being however largely different: 2534 bp and 20510 bp for the BHMT gene and 1465 bp and 4239 bp for the PGDS gene for $P$. flesus and $H$. sapiens respectively.

\section{Genetic variability within populations}

Flounder populations showed limited departure from Hardy-Weinberg equilibrium, except for the GAPDH locus, where strong heterozygote deficits were observed. These deficiencies for GAPDH locus may be explained by technical artefacts such as the existence of null allele and/or the poor allele discrimination (Lundy et al., 1999); these deficiencies being observed in all five studied populations.

Other loci displayed limited values of heterozygote excess or deficit, although not at a significant level. The CK locus appeared to be at Hardy-Weinberg equilibrium, as Fis values were very close to zero. For the three other loci (p53, BHMT, PGDS), only some populations showed heterozygote excess or deficit. This situation is not indicative of a Wahlund effect, since populations that deviate from Hardy-Weinberg expectations are different according to the loci. Non random reproduction and small size of the natural populations are also unlikely, because flounder population sizes are generally considered as important in large estuaries of the French coast (Masson, 1988). Strong genetic mixing occurs generally during the reproduction period by the gathering of individuals for spawning (Berrebi, 1988; Masson, 1988; Borsa et al., 1997), thus non random reproduction is unlikely. A sampling bias could be at the origin of these differences, but the existence of a selective pressure acting on these three 
loci (p53, BHMT, PGDS) in contaminated areas could be also suggested, as it was in previous studies focusing on the same fish species and in the same estuaries (Laroche et al., 2002; Marchand et al., 2004). In these last studies, several allozyme loci were probably submitted to a selective pressure induced by the chemical stress.

\section{Genetic differentiation}

We hypothesised the presence of null alleles for GAPDH locus, thus the genetic differentiation linked to this loci is probably biased. Consequently, the previous loci will not be individually considered in the following discussion on the genetic differentiation.

Global multi-locus estimation of Fst between populations indicated a low level of genetic differentiation, with PGDS explaining the majority of this differentiation. This result suggests a high gene flow between populations. Since the marine environment is generally considered as a highly dispersive environment, low levels of genetic structure are commonly observed for marine species (Ward et al., 1994; Graves, 1998; Waples, 1998). For the flounder, the possible gathering of adults stemming from different areas in spawning aggregations at the mouth of the estuaries, combined with the high dispersal potential of its pelagic eggs and larvae (several weeks in the plankton), may explain effective connection between populations (Borsa et al., 1997). The previous authors also found a weak pattern of differentiation by distance for flounder populations from the South-Western Baltic Sea to Southern Portugal with allozyme markers. However, the weak genetic structure detected in our study, may also be linked, as for allozymes, to a reduced genetic variability of our DNA markers showing a limited allelic diversity (between two and five).. Moreover, the genetic differentiation detected between the Gironde and the Seine estuaries, particularly at the CK and PGDS loci, may be more related to the geographical distance than to a differential pollution context, since these estuaries are the most distant over the whole data set.

However, considering neutral markers like microsatellites, flatfish populations are generally weakly structured over large geographical distances in the North East Atlantic; this trend was particularly observed for the flounder (Hemmer-Hansen et al., 2007a), the plaice (Hoarau et al., 2002) and the sole (Rolland et al., 2007). Thus, we suggest that the patterns of genetic structuration detected for the flounder in our study are probably more linked to local selection of contrasted environments on the candidate genes than to the consequence of geographical distance between estuaries (i.e. possible isolation by distance, or different history of colonization). A convergent hypothesis was formulated by Hemmer-Hansen et al. (2007b) working on the genetic structure of flounder populations in the northern part of the 
species distribution, and considering a candidate gene (Hsc 70) and microsatellites; they concluded that the genetic structure among Atlantic and western Baltic Sea samples was more related to alternative factor (environmental gradient) than to the geographical distance itself.

Despite the low global multi-locus genetic differentiation, the single locus differentiation between pairs of populations and the distribution of allelic frequencies give a more subtle vision of the genetic structure. The genetic differentiation, considering a particular locus and the different pairs of populations could be linked to the potential selective pressure of the cocktails of contaminants, the analysis of pollutants in fish tissues displaying contrasted patterns of contamination (1) between the reference and the contaminated estuaries, and (2) between the contaminated estuaries (Evrard et al., 2010). One sequence polymorphism was identified at codon 134 of the p53 locus. It was identified previously as well as twenty one other polymorphisms in P. flesus from different locations (Cachot et al., 2000, Franklin et al., 2000). Pairwise Fst values for the p53 locus indicated that a genetic differentiation was observed between the Ster estuary (reference site) and the other contaminated estuaries (however non-significant). This difference might be related to the chemical stress and potentially reflects the existence of pollutants acting as selective agents in chronically contaminated populations in large estuaries. The distribution of allelic frequencies highlighted several convergences between contaminated sites compared to the reference site; thus an increase of the frequency of the A allele was observed in contaminated estuaries with respect to the Ster. As p53 is a crucial protein involved in cell growth control and maintenance of genome integrity, individuals carrying the p53 A allele could potentially be selected by chemical pressure. The hypothesis of a possible "resistant character" associated to the p53 A allele in contaminated systems is formulated. The selective pressure may select A alleles: (1) directly, through their differential efficiency (particular alleles being more efficient than others) or (2) indirectly, through hitchhiking phenomenon (linkage disequilibrium, e.g. non-random, interdependent, arrangement of alleles at different loci). The polymorphism observed at exon 4 conducts to silent mutations, privileging thus the hypothesis of a hitchhiking phenomenon acting on this locus. Nevertheless, such hypothesis should be supported by larger sample sizes and temporal replicates to strengthen the results. Genotypephenotype coupling as well as gene expression on p53 should also be performed in the future, to explore the functional role of the p53 polymorphism.

For the PGDS locus, a significant genetic differentiation between estuaries was found. Moreover, an increase of the A allele at this locus is observed in the Vilaine estuary compared 
to the Ster and to other estuaries. PGDS is an enzyme involved in important metabolic processes i.e. the synthesis of prostaglandins (Inoue, 2008) and some authors underlined that it may be involved in xenobiotics detoxification (Vogel, 2000). Given that the Vilaine estuary is submitted to a pesticide stress due to intensive agricultural practises and because PGDS is differentially expressed in response to pesticides exposure (Marchand et al., 2006), it is hypothesized that the cocktail of pesticides of this estuary acts as a selective agent on the PGDS locus, favouring the A allele. Mutations detected for PGDS lead to amino acid changes but however no difference in the secondary structure of the different variants was detected; indeed, valine, alanine and isoleucine (alleles A, B and E) belong to non-polar hydrophobic amino acids and acid aspartic and acid glutamic (allele C) are both acidic polar amino acids. Selective pressure potentially detected on this locus may thus act indirectly on the different protein sequences through hitchhiking phenomenon as it is hypothesized for p53.

\section{Perspectives}

New investigations are developed now in our laboratory, on the previous flounder populations stemming from environmentally contrasted estuaries; the main objective is to confirm the possible selective effects of the contaminants on the candidate genes investigated in this study: (1) by increasing the sample sizes of each population as well as examining temporal replicates to strengthen the results found in this study, (2) by comparing the genetic structure of the populations found with the previous candidate genes versus the structure found with neutral markers like microsatellites; neutral loci across the genome will be similarly affected by demography and the evolutionary history of populations, and loci under selection will behave differently and therefore reveal 'outlier' patterns of variation (Luikart et al., 2003); and (3) by exploring thoroughly the possible couplings between genotypes and phenotypes (associated gene expression, load of contaminants, DNA damages, liver pathologies) in the field.

\section{Acknowledgments}

The authors are grateful to the fisherman J.Gouyen and to the "Côte d'Aquitaine" crew for sampling and field assistance, as well as to G. Charrier and A. Tanguy for lab assistance. Research was performed at the Institut Universitaire Européen de la Mer, Plouzané, France. 
This research was financially supported by the project EVOLFISH (ANR program 2008:

Vulnérabilité, Milieux, Climats et Société).

\section{References}

Altschul, S.F., Gish, W., Miller, W., Myers, E.W. \& Lipman, D.J., 1990. Basic Local Alignment Search Tool. Journal of Molecular Biology 215: 403-410.

Aoki, T., Naka, H., Katagiri, T. \& Hirono, I., 2000. Cloning and characterization of glyceraldehyde- 3-phosphate dehydrogenase cDNA of Japanese flounder Paralichthys olivaceus. Fisheries Science 66: 737-42.

Belkhir, K., Borsa, P., Chikhi, L., Raufaust, N. \& Bonhomme, F., 2004. GENETIX 4.05, logiciel sous Windows pour la génétique des populations. Laboratoire Génome, Populations, Interactions, CNRS UMR 5000. Université de Montpellier II, Montpellier, France.

Benjamini, Y., Yekutieli,D., 2001. The control of the false discovery rate in multiple testing under dependency. Annals of Statistics 29(4) : 1165-1188.

Benton, M.J., Diamond, S.A. \& Guttman, S.I., 1994. A Genetic And Morphometric Comparison Of Helisoma-Trivolvis And Gambusia-Holbrooki From Clean And Contaminated Habitats. Ecotoxicology And Environmental Safety 29: 20-37.

Berrebi, P. 1988. Génétique des populations marines: le modèle «flet » (Platichthys flesus L. 1758, Téléostéen, Pleuronectidé). Thèse d'état, Université des Sciences et Techniques du Languedoc, Montpellier. pp. 246.

Berghmans, S., Murphey, R.D., Wienholds, E., Neuberg, D., Kutok J.L., Fletcher, C.D.M., Morris, J.P., Liu T.X., Schulte-Merker S., Kanki J.P., Plasterk R., Zon L.I. \& Look A.T., 2005. tp53 mutant zebrafish develop malignant peripheral nerve sheath tumors. Proceedings of the National Academic Science of USA, 102: 407-412.

Bickham, J.W., Sandhu, S., Hebert, P.D.N., Chikhi, L. \& Athwal, R., 2000. Effects of chemical contaminants on genetic diversity in natural populations: implications for biomonitoring and ecotoxicology. Mutation Research/Reviews in Mutation Research 463: 33-51.

Borsa, P., Blanquer, A. \& Berrebi, P., 1997. Genetic structure of the flounders Platichthys flesus and P. stellatus at different geographic scales. Marine Biology 129: 233-246.

Cachot, J., Galgani, F. \& Vincent, F., 1998. cDNA cloning and expression analysis of flounder p53 tumour suppressor gene. Comparative Biochemistry and Physiology part B 121: 235-242.

Cachot, J., Cherel, Y., Galgani, F. \& Vincent, F., 2000. Evidence of p53 mutation in an early stage of liver cancer in European flounder, Platichthys flesus (L.). Mutation ResearchGenetic Toxicology And Environmental Mutagenesis 464: 279-287.

Cachot, J., Flaman, J.-M., Frébourg, T.\& Leboulenger, F, 2004. The European flounder (Platichthys flesus) TP53 functions as a temperature-sensitive transcription factor which inhibits cell growth in yeast. Gene 324: 97-104 
Cachot, J., Geffard, O., Augagneur, S., Lacroix, S., Le Menach, K., Peluhet, L., Couteau, J., Denier, X., Devier, M.H., Pottier, D. \& Budzinski, H., 2006. Evidence of genotoxicity related to high PAH content of sediments in the upper part of the Seine estuary (Normandy, France). Aquatic Toxicology 79: 257-267.

Carvalho, G.R., 1993. Evolutionary Aspects of Fish Distribution - Genetic-Variability And Adaptation. Journal of Fish Biology 43: 53-73.

Chen, X.X., Wang, S., Wu, N., Sood, S., Wang, P., Jin, Z., Beer, D.G., Giordano, T.J., Lin, Y., Shih, W.C.J., Lubet, R.A. \& Yang, C.S., 2004. Overexpression of 5-lipoxygenase in rat and human esophageal adenocarcinoma and inhibitory effects of zileuton and celecoxib on carcinogenesis. Clinical Cancer Research 10: 6703-6709.

Chuang, D.M., Hough, C. \& Senatorov, V.V., 2005. Glyceraldehyde-3-phosphate dehydrogenase, apoptosis, and neurodegenerative diseases. Annual Review of Pharmacology and Toxicology 45: 269-90.

Evrard, E., Devaux, A., Bony, S., Burgeot, T., Riso, R., Budzinski, H., Le Du, M., Quiniou, L., Laroche, J., 2010. Responses of the European flounder Platichthys flesus, to the chemical stress in estuaries: load of contaminants, gene expression, cellular impact and growth rate. Biomarkers 15(2): 111-127.

Fore, S.A., Guttman, S.I., Bailer, A.J., Altfater, D.J. \& Counts, B.V., 1995. Exploratory Analysis Of Population Genetic Assessment As A Water-Quality Indicator.1. Pimephales Notatus. Ecotoxicology And Environmental Safety 30: 24-35.

Forget, J., 1998. Impact neurotoxique de contaminants (pesticides et métaux) sur un crustacé marin Tigriopus brevicornis (Müller). Caractérisation de la cholinestérase et application à la surveillance des effets des polluants sur l'environnement marin. Thèse de Doctorat de l'Université de Paris VI.

Franklin, T.M., Lee, J.S., Kohler, A. \& Chipman, J.K., 2000. Analysis of mutations in the p53 tumor suppressor gene and $\mathrm{Ki}$ - and Ha-ras proto-oncogenes in hepatic tumors of European flounder (Platichthys flesus). Marine Environmental Research 50: 251-255.

Fujimori, K., Inui, T., Uodome, N., Kadoyama, K., Aritake, K. \& Urade, Y., 2006. Zebrafish and chicken lipocalin-type prostaglandin D synthase homologues: Conservation of mammalian gene structure and binding ability for lipophilic molecules, and difference in expression profile and enzyme activity. Gene 375: 14-25.

Gillespie, R.B. \& Guttman, S.I., 1993. Correlation between water quality and frequencies of allozymes genotypes in spotfin shiner (Notropis spilopteris) populations. Environmental Pollution 81: 147-150.

Gillespie, R.B. \& Guttman, S.I., 1999. Chemical-induced changes in the genetic structure of populations: effects on allozymes. In: Genetics and Ecotoxicology (eds. Forbes V.E.). Taylor and Francis, p55-77.

Graves, J.E., 1998. Molecular insights into the population structures of cosmopolitan marine fishes. Journal of Heredity 89: 427-437.

Greenblatt, M.S., Bennett, W.P., Hollstein, M. \& Harris, C.C., 1994. Mutations in the p53 tumor suppressor gene: clues to cancer etiology and molecular pathogenesis. Cancer Research 54: 4855-4878.

Guo, S.W. \& Thompson, E.A., 1992. Performing the exact test of Hardy Weinberg proportions for multiple alleles. Biometrics 48: 361-372. 
Heithaus, M.R. \& Laushman, R.H., 1997. Genetic variation and conservation of stream fishes: influence of ecology, life history, and water quality. Canadian Journal Of Fisheries And Aquatic Sciences 54: 1822-1836.

Hemmer-Hansen, J., Nielsen, E., Frydenberg, J. \& Loeschcke, V., 2007b. Adaptive divergence in a high gene flow environment: Hsc70 variation in the European flounder (Platicthys flesus L.). Heredity 99: 592-600.

Hemmer-Hansen, J., Nielsen, E. \& Loeschcke, V., 2007a. Evolutionary mechanisms shaping the genetic population structure of marine fishes; lessons from the European flounder (Platichthys flesus L.). Molecular Ecology 16: 3104-3118.

Herrmann, W., 2006. Significance of hyperhomocysteinemia. Clinical Laboratory 52: 367374.

Hirai, H., Tanaka, K., Yoshie, O., Ogawa, K., Kenmotsu, K., Takamori, Y., Ichimasa, M., Sugamura, K., Nakamura, M., Takano, S. \& Nagata, K., 2001. Prostaglandin D2 selectively induces chemotaxis in T helper type 2 cells, eosinophils, and basophils via seven-transmembrane receptor CRTH2. Journal of Experimental Medicine 193: 255261.

Hoarau, G., Rijnsdorp, D., van der Veer,H.W., Stam, W.T., Olsen, J.L., 2002. Population structure of plaice (Pleuronectes platessa L.) in northern Europe: microsatellites revealed large-scale spatial and temporal homogeneity. Molecular Ecology 11: 11651176.

Hochachka, P.W., Dobson, G.P. \& Mommsen, T.P., 1983. Role of isozymes in metabolic regulation during exercise: insights from comparative studies. Isozymes Current Topics in Biological and Medical Research 8: 91-113.

Hodgson, E. \& Levi, P.E., 1991. The flavin-containing monooxygenase (EC 1.14.13.8). In: Molecular aspects of monooxygenases and bioactivation of toxic compounds, (eds. Arine E., Schankman J.B \& Hodgson E.). Plenum Press, New York, pp. 11-21.

Hodgson, E. \& Levi, P.E., 1992. The role of flavin-containing monooxygenase (EC 1.14.13.8) in the metabolism and mode of action of agricultural chemicals. Xenobiotica 22: 11751183.

Hornemann, T., Stolz, M. \& Wallimann, T., 2000. Isoenzymespecific interaction of muscletype creatine kinase with the sarcomeric M-line is mediated by NH2-terminal lysine charge- clamps. Journal of Cell Biology 149: 1225-1234.

Inoue, T., Eguchi, Y., Matsumoto, T., Kijima, Y., Kato, Y., Ozaki, Y., Waseda, K., Oda, H., Seiki, K. \& Node, K., 2008. Lipocalin-type prostaglandin D synthase is a powerful biomarker for severity of stable coronary artery disease. Atherosclerosis 201: 385-391.

Larno, V., Laroche, J., Launey, S., Flammarion, P.\& Devaux, A., 2001. Responses of chub (Leuciscus cephalus) populations to chemical stress, assessed by genetic markers, DNA damage and cytochrome P4501A induction. Ecotoxicology 10: 145-158.

Laroche, J., Quiniou, L., Juhel, G., Auffret, M. \& Moraga, D., 2002. Genetic and physiologic responses of flounder (Platichthys flesus) populations to chemical contamination in estuaries. Environmental Toxicology and Chemistry 21: 2705-2712. 
Langheinrich, U., Hennen, E., Stott, G. \& Vacun G., 2002. Zebrafish as a model organism for the identification and characterization of drugs ans genes affecting p53 signaling. Current Biology 12 : 2023-2028.

Leberg, P.L., 1992. Effects Of Population Bottlenecks On Genetic Diversity As Measured By Allozyme Electrophoresis. Evolution 46: 477-494.

Li, F., Feng, Q., Lee, C., Wang, S., Pelleymounter, L., Moon, I., Eckloff, B., Wieben, E., Schaid, D., Yee, V. \& Weinshilboum, R., 2008. Human betaine-homocysteine methyltransferase (BHMT) and BHMT2: Common gene sequence variation and functional characterization. Molecular Genetics and Metabolism 94: 326-335.

Liaud, M.F., Lichtle, C., Apt, K., Martin, W. \& Cerff, R., 2000. Compartment-specific isoforms of TPI and GAPDH are imported into diatom mitochondria as a fusion protein: evidence in favor of a mitochondrial origin of the eukaryotic glycolytic pathway. Molecular Biology and Evolution 17:213-23.

Luikart, G., England, P., Tallmon, D., Jordan, S., Taberlet, P., 2003. The power and promise of population genomics: From genotyping to genome typing. Nature Reviews Genetics 4: 981-994.

Lundy, C.J., Moran, P., Rico, C., Milner, R.S. \& Hewitt, G.M., 1999. Macrogeographical population differentiation in oceanic environments: a case study of European hake (Merluccius merluccius), a commercially important fish. Molecular Ecology 8: 1889_ 1898.

Ma, X.L., Cowles, D.L. \& Carter, R.L., 2000. Effect of pollution on genetic diversity in the bay mussel Mytilus galloprovincialis and the acorn barnacle Balanus glandula. Marine Environmental Research 50: 559-563.

Marchand, J., Tanguy, A., Laroche, J., Quiniou, L. \& Moraga, D., 2003. Responses of European flounder Platichthys flesus populations to contamination in different estuaries along the Atlantic coast of France. Marine Ecology Progress Series 260: 273284.

Marchand, J., Quiniou, L., Riso, R., Thebault, M.T. \& Laroche, J., 2004. Physiological cost of tolerance to toxicants in the European flounder Platichthys flesus, along the French Atlantic Coast. Aquatic toxicology 70: 327-343.

Marchand, J., Tanguy, A., Charrier, G., Quiniou, L., Plee-Gauthier, E. \& Laroche, J., 2006. Molecular Identification and Expression of Differentially Regulated Genes of the European Flounder, Platichthys flesus, submitted to Pesticide Exposure. Marine Biotechnology 8 : 275-294.

Masson, G., 1987. Biologie et écologie d'un poisson plat amphihalin, le Flet (Platichthys flesus flesus, Linné, 1758) dans l'environnement ligérien: distribution, démographie, place au sein des réseaux trophiques. Thèse de doctorat de l'Université de Bretagne Occidentale. pp. 370.

Menesguen, A., Aminot, A., Belin, C., Chapelle, A., Guillaud, J.-F., Joanny, M., Lefebvre, A., Merceron, M., Piriou, J.-Y. \& Souchu, P., 2001. L'eutrophisation des eaux marines et saumâtres en Europe, en particulier en France. Rapport IFREMER pour la Commission Européenne - DG.ENV.B1, 59p.

Moraga, D., Mdelgi-Lasram, E., Romdhane, M.S., Abed, A.E., Boutet, I., Tanguy, A. \& Auffret, M., 2002. Genetic responses to metal contamination in two clams: Ruditapes decussatus and Ruditapes philippinarum. Marine environmental research 54 : 521-525. 
Munschy, C., Mosan, K., Truquet, I. \& Tronczynski, J., 1997. Caractérisation chimique de la contamination organique dans l'estuaire de la Seine. Rapport Seine-Aval 1996, Agence de l'Eau Seine-Normandie, France.

Orita, M., Iwahana, H., Kanazawa, H., Hayashi, K. \& Sekiya, T., 1989. Detection of polymorphisms of human DNA by gel electrophoresis as single-strand conformation polymorphisms. Proceedings of the National Academy of Sciences USA 86: 27662770.

Ou, X., Yang, H., Ramani, K., Ara, A.I., Chen, H., Mato, J.M. \& Lu, S.C., 2007. Inhibition of human betaine-homocysteine methyltransferase expression by S-adenosylmethionine and methylthioadenosine. Biochemical journal 401: 87-96.

Piry, S., Alapetite, A., Cornuet, J.-M., Paetkau, D., Baudouin, L. \& Estoup, A., 2004. GeneClass2: A Software for Genetic Assignment and First-Generation Migrant Detection. Journal of Heredity 95: 536-539.

Pluquet, O. \& Hainaut, P., 2001. Genotoxic and non-genotoxic pathways of p53 induction. Cancer Letter 174: 1-15.

Raymond, M. \& Rousset, F., 1995. Genepop (Version-1.2) - Population-Genetics Software For Exact Tests And Ecumenicism. Journal of Heredity 86: 248-249.

Refsum, H., Ueland, P.M., Nygard, O. \& Vollset, S.F., 1998. Homocysteine and cardiovascular disease. Annual Review of Medicine 49: 31-62.

Rolland, J.L., Bonhomme, F., Lagardère, F., Hassan, M., Guinand, B., 2007. Population structure in the Northeastern Atlantic and the Mediterranean Sea : revisiting the divide with EPIC markers. Marine Biology 151 : 327-341.

RNO (Réseau National d'Observation), 2001. Surveillance du milieu marin. Travaux du Réseau National d'Observation de la qualité du milieu (eds. Ifremer).

SAGE (Schéma d'aménagement et de gestion des eaux) Vilaine, 1999. Projet de schéma d'aménagement et de gestion des eaux de la Vilaine, Atlas. Institution d'Aménagement de la Vilaine, La Roche Bernard.

Schwede, T., Kopp, J., Guex, N. \& Peitsch, M.C. 2003. SWISS-MODEL: an automated protein homology-modeling server. Nucleic Acids Research 31: 3381-3385.

Sheffield, V.C., Beck, J.S., Kwitek, A.E., Sandstrom, D.W. \& Stone, E.M., 1993. The sensitivity of single-strand conformation polymorphism analysis for the detection of single base substitutions. Genomics 16: 325-332.

Sirover, M.A., 1999. New insights into an old protein: the functional diversity of mammalian glyceraldehyde-3-phosphate dehydrogenase. Biochimica et Biophysica Acta 1432: 159-84.

Sirover, M.A., 2005. New nuclear functions of the glycolytic protein, glyceraldehyde- 3phosphate dehydrogenase, in mammalian cells. Journal of Cell Biochemistry 95: 4552.

Strohman, R.C., Moss, P.S., Micou-Eastwood, J., Spector, D., Przybyle, A. \& Patterson, B., 1977. Messenger RNA for myosin polypeptides: isolation from single myogenic cell cultures. Cell 10: 265-273.

Su, B., Guan, M., Zhao, R.J. \& Lu, Y., 2001. Expression of prostaglandin D synthase in ovarian cancer. Clinical Chemistry And Laboratory Medicine 39: 1198-1203. 
Sueiro, R.A., Jenkins, G.J.S., Lyons, B.P., Harvey, J.S. \& Parry, J.M., 2000. Genotypic mutation analysis in the p53 gene of benzo[a]pyrene-treated European flounder (Platichthys flesus). Mutation Research-Genetic Toxicology And Environmental Mutagenesis 468: 63-71.

Tanguy, A., Boutet, I., Bonhomme, F., Boudry, P. \& Moraga, D., 2002. Polymorphism of metallothionein genes in the Pacific oyster Crassostrea gigas as a biomarker of response to metal exposure. Biomarkers 7: 439-450.

Tso, J.Y., Sun, X.H., Kao, T., Reece, K.S. \& Wu, R., 1985. Isolation And Characterization Of Rat And Human Glyceraldehyde-3-Phosphate Dehydrogenase Cdna - Genomic Complexity And Molecular Evolution Of The Gene. Nucleic Acids Research 13: 2485-2502.

van Deursen, J., Heerschap, A., Oerlemans, F., Ruitenbeek, W., Jap, P., ter Laak, H. \& Wieringa, B., 1993. Skeletal muscles of mice deficient in muscle creatine kinase lack burst activity. Cell 74: 621-631.

Vethaak, A.D., Pieters, J., Jol, J.G., 2009. Long-term trends in the prevalence of cancer and major diseases among flatfish in the S.E. North Sea as indicators of changing ecosystem health. Environmental Science and Technology 43: 2151-2158.

Vogel, C., 2000. Prostaglandin H synthases and their importance in chemical toxicity. Current drugs 1: 391-404.

Wallimann, T. \& Eppenberger, H.M., 1985. Localization and function of M-line bound creatine kinase. Cell and Muscle Motility 6: 239-285.

Wallimann, T., Wyss, M., Brdiczka, D., Nicolay, K. \& Eppenberger, H.M., 1992. Intracellular compartmentation, structure and function of creatine kinase isoenzymes in tissues with high and fluctuating energy demands: the 'phosphocreatine circuit' for cellular energy homeostasis. Biochemistry Journal 281: 21-40.

Waples, R.S. \& Rosenblatt, R.H., 1987. Patterns of larval drift in Southern California marine shore fishes inferred from allozyme data. Fishery Bulletin 85: 1-12.

Ward, R.D., Woodward, M. \& Skibinski, D.O.F., 1994. A comparison of genetic diversity levels in marine, freshwater, and anadromous fishes. Journal of Fish Biology 4: 213232.

Weir, B.S. \& Cockerham, C.C., 1984. Estimating F-statistics for the analysis of population structure. Evolution 38: 1358-1370.

Wright, S., 1969. Evolution and the genetics of populations, Vol. 2: The theory of gene frequencies. University of Chicago Press, Chicago. 
Table 1: Primers designed for cDNA amplifications. The F and R letters found in the Primer name indicate respectively forward $(\mathrm{F})$ and reverse $(\mathrm{R})$ primers; Ta: annealing temperatures of the different primers.

\begin{tabular}{|c|c|c|}
\hline Primer name & Primer sequence & Ta $\left({ }^{\circ} \mathbf{C}\right)$ \\
\hline GAPDH F 1 & 5'-GTGTCTTCACCACCATTGAGAAGGC-3' & 61 \\
\hline GAPDH $R_{1}$ & 5'-ATTGGCTGCTCGGTTTACTCCTTGGC-3' & 65 \\
\hline $\mathrm{CK} \mathrm{F}_{1}$ & 5'-GGTTCTGACCAAGGAGCTGTATGGC-3' & 62 \\
\hline $\mathbf{C K ~ R}_{1}$ & 5'-GGACACGGCTGGACAGAACATAGTTG-3' & 62 \\
\hline PGDS F $_{1}$ & 5'-ACGTTGTCGGCTATGCCTCCAACG-3' & 65 \\
\hline PGDS R & 5'-CGGCTGAGGAGGTTGTTGAGGATG-3' & 64 \\
\hline BHMT $F_{1}$ & 5'- ACACTGGGAAACAGAGATGGCACCT-3' & 62 \\
\hline BHMT $R_{1}$ & 5'-TCCAGTGATACTGAGTGTCTGACCC-3' & 57 \\
\hline Oligo dt Race primer & 5'-GACCACGCGTATCGATGTCGACT $(16)^{-3}{ }^{\prime}$ & 72 \\
\hline Race primer & 5'-GACCACGCGTATCGATGTCGACT-3' & 61 \\
\hline
\end{tabular}

Table 2: Primers designed for gene amplifications (F: forward, R: reverse and Ta: annealing temperature).

\begin{tabular}{|c|c|c|c|}
\hline Primer name & Primer sequence & $\mathbf{T a}\left({ }^{\circ} \mathbf{C}\right)$ & $\begin{array}{l}\text { Fragment } \\
\text { amplified }\end{array}$ \\
\hline $\begin{array}{l}\text { GAPDH F } \\
\text { GAPDH R2 }\end{array}$ & \begin{tabular}{|l} 
5'-ATGGTGAAAGTTGGTATCAATGG-3' \\
5'-CTCAATGGTGGTGAAGACACCGGTGG-3'
\end{tabular} & $\begin{array}{l}55 \\
65\end{array}$ & 1993 bp \\
\hline $\begin{array}{l}\text { GAPDH F }_{3} \\
\text { GAPDH R }\end{array}$ & $\begin{array}{l}\text { 5'-GTGTCTTCACCACCATTGAGAAGGCC-3' } \\
\text { 5'-TGGGATGATGTTCTGGCTGGCACCGC-3' }\end{array}$ & $\begin{array}{l}63 \\
66\end{array}$ & 677 bp \\
\hline $\begin{array}{l}\text { GAPDH F }_{4} \\
\text { GAPDH R}_{4}\end{array}$ & $\begin{array}{l}\text { 5'-AACATCATCCCAGCTTCAACTGGTGCCGC-3' } \\
\text { 5'-ATTGGCTGCTCGGTTTACTCCTTGGC-3' }\end{array}$ & $\begin{array}{l}66 \\
63\end{array}$ & $1060 \mathrm{bp}$ \\
\hline $\begin{array}{l}\text { CK } \mathbf{F}_{2} \\
\mathbf{C K ~ R _ { 2 }}\end{array}$ & $\begin{array}{l}\text { 5'-ATGCCTTTCGGAAACACCCACAACA-3' } \\
\text { 5'-AGATGAGATTGTTCCTCTCTACTT-3' }\end{array}$ & $\begin{array}{l}59 \\
55\end{array}$ & $1963 \mathrm{bp}$ \\
\hline $\begin{array}{l}\text { PGDS F } \\
\text { PGDS } R_{2}\end{array}$ & $\begin{array}{l}\text { 5'-AGCAACATGATGAACTCGCT-3' } \\
\text { 5'-TCAGGCCCGGTGACATTGGA-3' }\end{array}$ & $\begin{array}{l}52 \\
58\end{array}$ & $1123 \mathrm{bp}$ \\
\hline $\begin{array}{l}\text { BHMT F }_{2} \\
\text { BHMT R R }_{2}\end{array}$ & $\begin{array}{l}\text { 5'-CACTGGGAAACAGAGATGGCA-3' } \\
\text { 5'-AAGATGCCCTTCACTTCTGTCTC -3' }\end{array}$ & $\begin{array}{l}57 \\
57\end{array}$ & $1085 \mathrm{bp}$ \\
\hline $\begin{array}{l}\text { BHMT F }_{3} \\
\text { BHMT R R }\end{array}$ & $\begin{array}{l}\text { 5'- GAGACAGAAGTGAAGGGCATCTT -3' } \\
\text { 5'- GTGTGCATCTCCAGACCAGCG-3' }\end{array}$ & $\begin{array}{l}57 \\
60\end{array}$ & $938 \mathrm{bp}$ \\
\hline $\begin{array}{l}\text { BHMT F }_{4} \\
\text { BHMT R R }_{4}\end{array}$ & $\begin{array}{l}\text { 5'- AGAGAGGCCTACAAGGCTGGA-3' } \\
\text { 5'- TTGACCGAGGACACTCTCGC -3' }\end{array}$ & $\begin{array}{l}59 \\
58\end{array}$ & $487 \mathrm{bp}$ \\
\hline
\end{tabular}


Table 3: Primers designed for PCR-SSCP amplifications (F: Forward, R: Reverse and Ta: annealing temperature).

\begin{tabular}{|c|c|c|c|}
\hline Primer name & Primer sequence & Ta $\left({ }^{\circ} \mathbf{C}\right)$ & $\begin{array}{l}\text { Fragment } \\
\text { amplified }\end{array}$ \\
\hline $\begin{array}{l}\text { GAPDH F }_{5} \\
\text { GAPDH R5 }\end{array}$ & $\begin{array}{l}\text { 5'-CCTTGTCTCCTCCCTCTTTAG-3' } \\
\text { 5'-GTTGAGGACTGAGTACGTAC-3' }\end{array}$ & 56 & $380 \mathrm{bp}$ \\
\hline 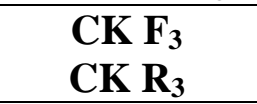 & $\begin{array}{l}\text { 5'-TCCTCTTTCTTATTTAACAG-3' } \\
\text { 5'-AGATGAGATTGTTCCTCTCTACTT-3' }\end{array}$ & 55 & $364 \mathrm{bp}$ \\
\hline $\begin{array}{l}\text { PGDS F }_{3} \\
\text { PGDS R }_{3}\end{array}$ & $\begin{array}{l}\text { 5'-TGTGTATTCCTGCTTTATCAG-3' } \\
\text { 5'-GCATTGATTCAAAAGCGTCTG-3' }\end{array}$ & 58 & $371 \mathrm{bp}$ \\
\hline $\begin{array}{l}\text { BHMT F }_{4} \\
\text { BHMT R R }_{4}\end{array}$ & $\begin{array}{l}\text { 5'-TGTGTTATTTTCAATAGTGCG-3' } \\
\text { 5'-ATACAGTGGTTGAACACTTAC-3' }\end{array}$ & 58 & $151 \mathrm{bp}$ \\
\hline $\begin{array}{l}\text { p53 F } \\
\text { p53 R }\end{array}$ & $\begin{array}{l}\text { 5'-GGCTTTCTCCCCGTGTTTCTCTCAG-3' } \\
\text { 5'-TACACTGATCACTTTACTTAC-3' }\end{array}$ & 55 & $221 \mathrm{bp}$ \\
\hline
\end{tabular}

Table 4: Molecular characterization

\begin{tabular}{|c|c|c|c|c|}
\hline Gene name & GAPDH & CK & PGDS & BHMT \\
\hline cDNA accession number & $\underline{\mathbf{A J 9 3 7 5 2 2}}$ & $\underline{\mathbf{F N 4 3 2 3 8 7}}$ & $\underline{\mathbf{F N 4 3 2 3 8 8}}$ & $\underline{\underline{\text { FN432389 }}}$ \\
\hline DNA accession number & $\underline{\mathbf{A J 9 3 7 5 2 1}}$ & $\underline{\mathbf{F N 4 3 2 3 9 0}}$ & $\underline{\mathbf{F N 4 3 2 3 9 1}}$ & $\underline{\mathbf{F N 4 3 2 3 9 2}}$ \\
\hline Coding region length (bp) & 999 & 1146 & 540 & 1206 \\
\hline Number of amino acids & 332 & 381 & 179 & 401 \\
\hline Molecular weight (kDa) & 35.87 & 43 & 20.15 & 43.98 \\
\hline Isoelectric point & 8.27 & 6.22 & 5.86 & 7.22 \\
\hline 5'UTR length (bp) & 73 & 93 & 25 & 67 \\
\hline 3'UTR length (bp) & 329 & 331 & 343 & 176 \\
\hline DNA length (bp) & 4086 & 2369 & 1465 & 2534 \\
\hline Number of introns & 10 & 6 & 5 & 7 \\
\hline Number of exons & 11 & 7 & 6 & 8 \\
\hline
\end{tabular}


Table 5: Allelic frequencies for each location and each locus. $\mathrm{N}=$ number of fish per estuary; Ho: mean observed heterozygosity; He: mean expected heterozygosity.

\begin{tabular}{|c|c|c|c|c|c|c|}
\hline & & Ster & Gironde & Loire & Seine & Vilaine \\
\hline$N$ & & 40 & 40 & 39 & 40 & 30 \\
\hline Ho & & 0,360 & 0,390 & 0,323 & 0,340 & 0,287 \\
\hline $\mathrm{He}$ & & 0,376 & 0,411 & 0,386 & 0,393 & 0,315 \\
\hline$\underline{\text { Locus }}$ & $\underline{\text { Allele }}$ & & & & & \\
\hline \multirow[t]{5}{*}{ GAPDH } & $\mathbf{A}$ & 0,675 & 0,563 & 0,667 & 0,637 & 0,683 \\
\hline & B & 0,163 & 0,300 & 0,128 & 0,138 & 0,167 \\
\hline & $\mathbf{C}$ & 0,125 & 0,138 & 0,205 & 0,188 & 0,150 \\
\hline & D & 0,013 & 0,000 & 0,000 & 0,025 & 0,000 \\
\hline & $\mathbf{E}$ & 0,025 & 0,000 & 0,000 & 0,013 & 0,000 \\
\hline \multirow[t]{4}{*}{ CK } & $\mathbf{A}$ & 0,887 & 0,813 & 0,872 & 0,925 & 0,917 \\
\hline & B & 0,050 & 0,050 & 0,051 & 0,063 & 0,033 \\
\hline & $\mathbf{C}$ & 0,063 & 0,087 & 0,038 & 0,000 & 0,033 \\
\hline & D & 0,000 & 0,050 & 0,038 & 0,013 & 0,017 \\
\hline \multirow[t]{2}{*}{ p53 } & $\mathbf{A}$ & 0,388 & 0,512 & 0,513 & 0,525 & 0,517 \\
\hline & B & 0,613 & 0,487 & 0,487 & 0,475 & 0,483 \\
\hline \multirow[t]{2}{*}{ ВНMT3 } & $\mathbf{A}$ & 0,825 & 0,850 & 0,872 & 0,850 & 0,933 \\
\hline & B & 0,175 & 0,150 & 0,128 & 0,150 & 0,067 \\
\hline \multirow[t]{5}{*}{ PGDS } & A & 0,738 & 0,775 & 0,679 & 0,613 & 0,833 \\
\hline & B & 0,263 & 0,163 & 0,295 & 0,338 & 0,150 \\
\hline & C & 0,000 & 0,050 & 0,013 & 0,037 & 0,017 \\
\hline & D & 0,000 & 0,013 & 0,013 & 0,000 & 0,000 \\
\hline & $\mathbf{E}$ & 0,000 & 0,000 & 0,000 & 0,013 & 0,000 \\
\hline
\end{tabular}


Table 6: Estimation of inbreeding coefficient (Fis) by locus for each location. Significance of Fis was assessed by Fisher's exact tests. Bold values indicated significant p-values, with ** for $\mathrm{p}<0.01$ and $* * *$ for $\mathrm{p}<0.001$.

\begin{tabular}{llllll}
\hline & Ster & Gironde & Loire & Vilaine & Seine \\
\hline GAPDH & $\mathbf{0 . 3 6 3} * * *$ & $\mathbf{0 . 3 5 8 * *}$ & $\mathbf{0 . 4 9 4} * * *$ & $\mathbf{0 . 5 2 9} * * *$ & $\mathbf{0 . 5 9 1} * * *$ \\
CK & -0.080 & -0.057 & -0.081 & -0.043 & -0.056 \\
P53 & -0.093 & -0.138 & 0.089 & -0.252 & 0.110 \\
BHMT & -0.026 & 0.032 & 0.323 & -0.054 & 0.032 \\
PGDS & -0.085 & -0.067 & -0.067 & 0.074 & -0.215 \\
\hline
\end{tabular}

Table 7: Single and multi-locus global assessment of genetic differentiation between estuaries using (1) Fst estimated with Weir \& Cockerham's $\partial$ and tested using 5000 permutations (* $\mathrm{p}<0.05)$ and (2) exact test ( $\mathrm{p}$-values) of genetic differentiation tested with the Markov chain method, using 3000 iterations.

\begin{tabular}{llccccc}
\hline & Multilocus & GAPDH & CK & p53 & BHMT & PGDS \\
& & & & & & \\
\hline $\boldsymbol{*}$ Exact test & 0.07 & -0.001 & 0.005 & 0.002 & -0.003 & $0.021^{*}$ \\
\hline
\end{tabular}


Table 8: Estimation of single-locus pairwise $\theta$ values with associated significance in bold. * for $\mathrm{p}<0.05$.

\begin{tabular}{|c|c|c|c|c|c|}
\hline$\theta$ & GAPDH & P53 & CK & BHMT & PGDS \\
\hline Ster - Seine & $-0,01278$ & 0,02507 & 0,00442 & $-0,01035$ & 0,01445 \\
\hline Ster - Vilaine & $-0,0198$ & 0,0213 & $-0,00766$ & $\mathbf{0 , 0 3 7 4 4} *$ & 0,01737 \\
\hline Ster - Gironde & 0,01252 & 0,02025 & 0,00452 & $-0,01035$ & 0,00676 \\
\hline Ster - Loire & $-0,00986$ & 0,01883 & $-0,0065$ & $-0,00586$ & $-0,00614$ \\
\hline Seine - Vilaine & $-0,01828$ & $-0,01399$ & $-0,00705$ & 0,01928 & $\mathbf{0 , 0 8 1 3 3} *$ \\
\hline Seine - Gironde & $\mathbf{0 , 0 1 2 5 8} *$ & $-0,01216$ & $\mathbf{0 , 0 3 3 3} *$ & $-0,01307$ & $\mathbf{0 , 0 5 1 3 1} *$ \\
\hline Seine - Loire & $-0,01796$ & $-0,01382$ & 0,00177 & $-0,01298$ & $-0,00337$ \\
\hline Vilaine - Gironde & 0,00891 & $-0,01196$ & 0,01537 & 0,01928 & $-0,00726$ \\
\hline Vilaine - Loire & $-0,01778$ & $-0,01404$ & $-0,00682$ & 0,00276 & 0,04219 \\
\hline Gironde - Loire & $\mathbf{0 , 0 2 2 6 3} *$ & $-0,01249$ & $-0,00118$ & $-0,01298$ & 0,02149 \\
\hline
\end{tabular}


Figure captions

Figure 1 Sampling sites: contaminated estuaries (Seine, Vilaine, Loire, Gironde) and reference estuary (Ster)

Figure 2: Molecular structure (exons/introns) of the 5 genes characterized: A) GAPDH, B) CK, C) BHMT, and D) PGDS. The length of each exon and intron is indicated below (bp). Fragments amplified by SSCP are also indicated.

Figure 3: Sequences of the different alleles detected for the 5 locus studied. 


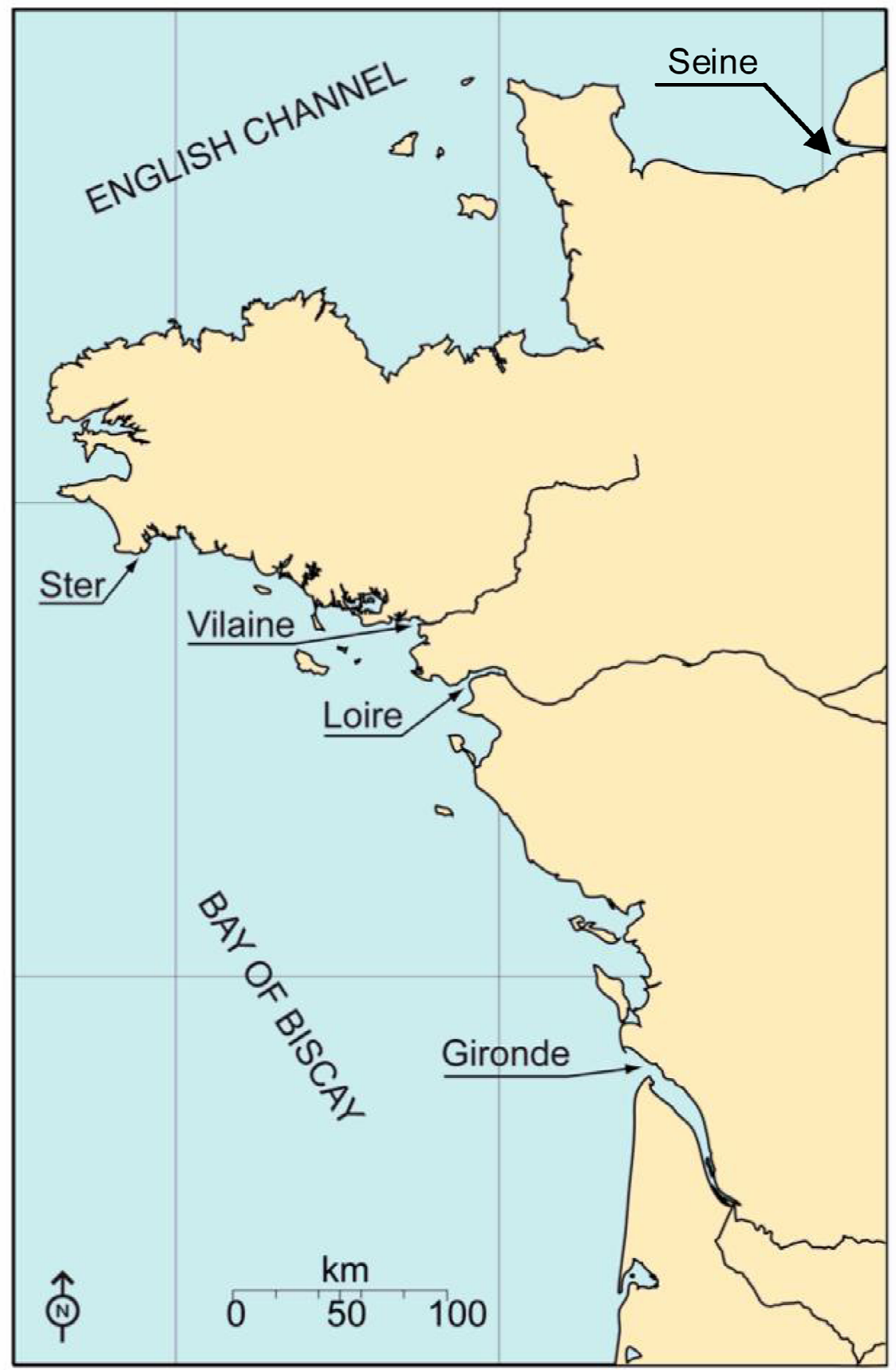

Figure 1 


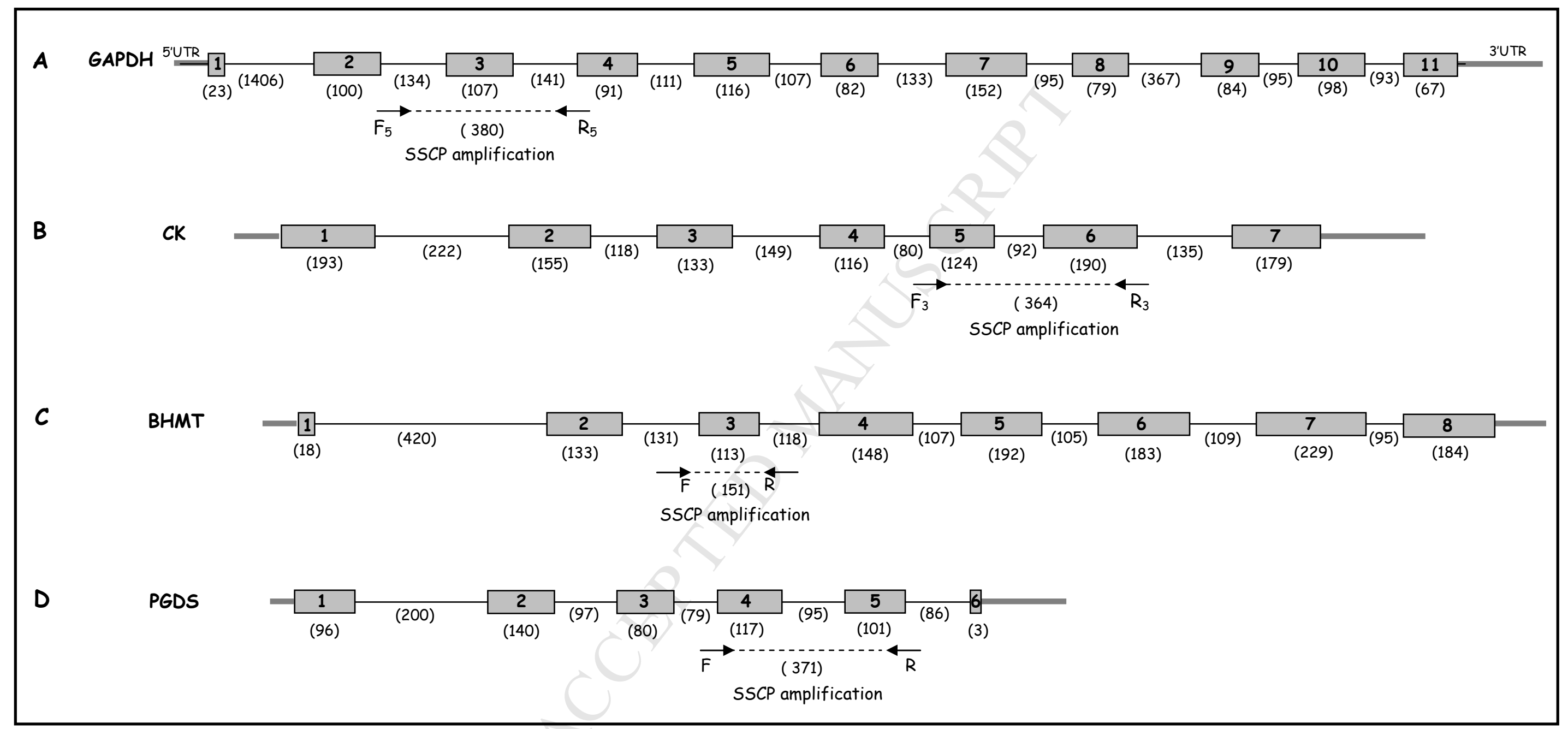

Figure 2 